\title{
Grey Correlation Analysis of Impact Factors for High-skilled Talents' Professional Accomplishment
}

\author{
Yuehua Chen \\ Changsha Aeronautical Vocational and Technical College, Hunan Province, China \\ 68224119@qq.com
}

\begin{abstract}
In order to clear the primary and secondary impact factors of high-skilled talents' professional accomplishment (HTPA) and facilitate the quantitative analysis, the paper indicates that the HTPA mainly displays in the dominant employment literacy and recessive enjoyment literacy. By using Grey Correlation theory, it concrete analyses the nine influence factors of HTPA in employment and enjoyment literacy respectively. The result shows that the correlation degree of each impact factors in employment and enjoyment are different, and what's more, the high frequency of factors does not necessarily mean the high degree of correlation. Therefore it, combining the frequency and correlation degree, explores the countermeasures of enhancement HTPA from three aspects: professional moral, professional ideal and professional ability.
\end{abstract}

Index Terms - Grey correlation, impact factors, HTPA, recommendations

\section{Introduction}

As the code of conduct, professional accomplishment is comprehensively represented in professional skills and moral, and which people should abide by in specific work. The cultivation of HTPA is a step by step internalization process, which has lots of impact factors. Qualitative research is hard to get the primary and secondary influence factors, however the quantitative analysis requires the adequate data, and figures should be conformed to the typical probability distribution. Due to the limited cases and poor information, this paper will apply the grey correlation to analyse the impact factors of HTPA.

\section{Index Selection and Data Sources}

\section{A. Index Selection of impact factors of HTPA}

The quality of HTPA [1] can be evaluated by the following four aspects: firstly, professional ethics such as respect and love own post, honest and trustworthy, contributing to society and services to the masses; secondly, professional abilities, which not only include the various adoptive methods to fulfil the task such as ways to learn, ways to think and ways to judge etc, but also embody the ability of organization, coordination and cooperation. Thirdly, it mainly focuses on the professional knowledge and skills, and that is the basis of successful employment. Last but not least, one's professional ideal is the main factor whether the people work in peace and contentment or not. With the principle of easilygot and quantitative data, the article lists the following nine factors on the basis of previous study, namely personality character $\mathrm{X}_{1}$, professional knowledge $\mathrm{X}_{2}$, professional skills $\mathrm{X}_{3}$, learning ability $\mathrm{X}_{4}$, social ability $\mathrm{X}_{5}$, professional ideal $\mathrm{X}_{6}$, professional ethics $\mathrm{X}_{7}$, family factors $\mathrm{X}_{8}$ and social motivation $\mathrm{X}_{9}$. In order to comprehensively study the impact factors of HTPA, the paper holds a view that the HTPA mainly displays in the dominant employment literacy and recessive enjoyment literacy and it shows as following employment rate $\mathrm{X}_{01}$ and enjoyment rateX $\mathrm{X}_{02}$.

\section{B. Data Collection}

In order to make the data more scientific and objective, the paper takes four consecutive sessions of 180 graduates from 2008-2011 in our college as the study object. By the statistics, the original data and frequency of various impact factors of employment literacy and enjoyment literacy respectively shows in table I and table II.

TABLE I Original Data of Impact Factors of Employment Literacy

\begin{tabular}{|c|c|c|c|c|c|c|}
\hline Items & 2008 & 2009 & 2010 & 2011 & Frequency & Order \\
\hline $\mathrm{X}_{01}(\%)$ & 87.66 & 88.96 & 85.78 & 90.07 & & \\
\hline $\mathrm{X}_{1}$ & 27 & 22 & 18 & 35 & 102 & 6 \\
\hline $\mathrm{X}_{2}$ & 35 & 37 & 19 & 28 & 119 & 4 \\
\hline $\mathrm{X}_{3}$ & 30 & 39 & 45 & 42 & 156 & 1 \\
\hline $\mathrm{X}_{4}$ & 18 & 22 & 23 & 33 & 96 & 8 \\
\hline $\mathrm{X}_{5}$ & 16 & 25 & 32 & 24 & 97 & 7 \\
\hline $\mathrm{X}_{6}$ & 32 & 37 & 30 & 40 & 139 & 3 \\
\hline $\mathrm{X}_{7}$ & 34 & 23 & 35 & 48 & 140 & 2 \\
\hline $\mathrm{X}_{8}$ & 9 & 25 & 10 & 17 & 61 & 9 \\
\hline $\mathrm{X}_{9}$ & 29 & 19 & 36 & 21 & 105 & 5 \\
\hline
\end{tabular}

TABLE II Original Data of Impact Factors of Enjoyment Literacy

\begin{tabular}{|c|c|c|c|c|c|c|}
\hline Items & 2008 & 2009 & 2010 & 2011 & Frequency & Order \\
\hline $\mathrm{X}_{02}(\%)$ & 67.45 & 58.46 & 56.58 & 70.23 & & \\
\hline $\mathrm{X}_{1}$ & 32 & 21 & 29 & 42 & 124 & 4 \\
\hline $\mathrm{X}_{2}$ & 22 & 23 & 27 & 28 & 100 & 8 \\
\hline $\mathrm{X}_{3}$ & 32 & 19 & 30 & 43 & 124 & 4 \\
\hline $\mathrm{X}_{4}$ & 36 & 43 & 27 & 39 & 145 & 2 \\
\hline $\mathrm{X}_{5}$ & 45 & 38 & 31 & 48 & 162 & 1 \\
\hline $\mathrm{X}_{6}$ & 29 & 40 & 32 & 28 & 129 & 3 \\
\hline $\mathrm{X}_{7}$ & 29 & 27 & 32 & 32 & 120 & 6 \\
\hline $\mathrm{X}_{8}$ & 18 & 22 & 20 & 19 & 79 & 9 \\
\hline $\mathrm{X}_{9}$ & 23 & 33 & 28 & 30 & 114 & 7 \\
\hline
\end{tabular}




\section{Calculation Methods and Result Analysis}

\section{A. Grey correlation theory}

Grey correlation theory [2] was founded in 1982 by Prof. Julong Deng, is an important part of grey system theory. As a quantitative analysis which is mainly through the generation, development and extracting valuable information from the known information to analyse the correlation degree of various impact factors in the grey system, so as to achieve the correct description of system and properly monitor the system behaviour. The theory does not have high requirements on sample, which generally to analyse the correlation degree of impact factors in the poor information, small sample. According to the similarity degree of sequence curve to determine its relation is close or not, if the curve of the system changes consistent with variable curve changes, is recognized as the strong correlation, otherwise, the connection on the weak.

\section{B. Grey Correlation Analysis}

\section{1) Dimensionless treatment}

The sequence of dependent variable, also called the mother sequence, denoted as: $\mathrm{X}_{01}(\mathrm{k})$ or $\mathrm{X}_{02}(\mathrm{k})$, system behaviour sequence, denoted as $X_{1}, X_{2} \ldots . . X_{9}$. The dimensionless treatment of original series aims to eliminate the different size of figures, and then the calculation and comparative analysis is easily made. The treatment is to assign each first variable as 1, and then compared to others to get dimensionless number.

\section{2) Correlation Coefficient and Correlation Degree}

By the following formula, absolute value between the mother sequence and each subsequence can be obtained, and then the maximum difference and minimum difference are got as stated below:

Absolute Value:

$$
\Delta_{i}(k)=\left|X_{0}(k)-X_{i}(K)\right|(i=1,2,3 \ldots 9)
$$

Maximum Difference:

$$
\Delta_{\max }=\max _{i} \max _{i}\left|x_{0}(k)-x_{i}(k)\right|
$$

Minimum Difference:

$$
\Delta_{\min }=\min _{i} \min _{i}\left|x_{0}(k)-x_{i}(k)\right|
$$

From table I: $\Delta_{\min }=0, \Delta_{\max }=1.7630$

From table II: $\Delta_{\min }=0, \Delta_{\max }=0.5481$

Then to calculate the correlation coefficient by the following formula, $\mathrm{L}_{0 \mathrm{i}}(\mathrm{k})$ represents the relevant difference of $\mathrm{k}$ point between sub-factors and parent factors, $\lambda$ stands for resolution ratio, which usually is selected by a certain numeral between $0 \sim 1$, such as $\lambda=0.5$.

$$
L_{0 i}(k)=\frac{\Delta_{\min }+\lambda \Delta_{\max }}{\Delta+\lambda \Delta_{\max }}
$$

By using the method of arithmetic average, the paper has got the grey correlation degree $\left(\mathrm{R}_{0 \mathrm{i}}\right)$ of each factor.

$$
R_{0 i}=\frac{1}{n} \sum_{k=1}^{n} L_{0 i}(k)
$$

\section{3) Relevancy}

The correlation degree is more close to 1 , it shows the two factors is of great relevance. According to previous study, when $\lambda=0.5$, the correlation degree of two factors is more than 0.7 , to be considered a significant relation. The correlation coefficient and correlation degree show in Table III table IV.

TABLE III Correlation Degree of Employment Rate and Impact Factors

\begin{tabular}{|c|c|c|c|c|c|c|}
\hline Items & 2008 & 2009 & 2010 & 2011 & $\begin{array}{c}\text { Correlation } \\
\text { Degree }\end{array}$ & Order \\
\hline $\mathrm{X}_{01}$ & 1 & 1.0148 & 0.9786 & 1.0275 & & \\
\hline $\mathrm{L}_{01}(1)$ & 1 & 0.8151 & 0.5694 & 0.4048 & 0.6973 & 6 \\
\hline $\mathrm{L}_{01}(2)$ & 1 & 0.9542 & 0.6692 & 0.7949 & 0.8546 & 1 \\
\hline $\mathrm{L}_{01}(3)$ & 1 & 0.7555 & 0.6283 & 0.7030 & 0.7717 & 5 \\
\hline $\mathrm{L}_{01}(4)$ & 1 & 0.4190 & 0.4082 & 0.3260 & 0.5383 & 9 \\
\hline $\mathrm{L}_{01}(5)$ & 1 & 0.6177 & 0.4632 & 0.6510 & 0.6830 & 7 \\
\hline $\mathrm{L}_{01}(6)$ & 1 & 0.8617 & 0.9555 & 0.4136 & 0.8077 & 3 \\
\hline $\mathrm{L}_{01}(7)$ & 1 & 0.7227 & 0.9455 & 0.6964 & 0.8412 & 2 \\
\hline $\mathrm{L}_{01}(8)$ & 1 & 0.3333 & 0.8693 & 0.5058 & 0.6771 & 8 \\
\hline $\mathrm{L}_{01}(9)$ & 1 & 0.7103 & 0.7703 & 0.7434 & 0.8060 & 4 \\
\hline
\end{tabular}

TABLE IV Correlation Degree of Enjoyment Rate and Impact Factors

\begin{tabular}{|c|c|c|c|c|c|c|}
\hline Items & 2008 & 2009 & 2010 & 2011 & $\begin{array}{c}\text { Correlation } \\
\text { Degree }\end{array}$ & Order \\
\hline $\mathrm{X}_{02}$ & 1 & 0.8667 & 0.8388 & 1.0412 & & \\
\hline $\mathrm{L}_{02}(1)$ & 1 & 0.5657 & 0.8024 & 0.5026 & 0.7177 & 5 \\
\hline $\mathrm{L}_{02}(2)$ & 1 & 0.6052 & 0.4137 & 0.5421 & 0.6403 & 8 \\
\hline $\mathrm{L}_{02}(3)$ & 1 & 0.5011 & 0.7352 & 0.4753 & 0.6779 & 6 \\
\hline $\mathrm{L}_{02}(4)$ & 1 & 0.4555 & 0.7553 & 0.8669 & 0.7694 & 3 \\
\hline $\mathrm{L}_{02}(5)$ & 1 & 0.9248 & 0.6465 & 0.9134 & 0.8712 & 1 \\
\hline $\mathrm{L}_{02}(6)$ & 1 & 0.3481 & 0.5088 & 0.7836 & 0.6601 & 7 \\
\hline $\mathrm{L}_{02}(7)$ & 1 & 0.8100 & 0.5088 & 0.8150 & 0.8033 & 2 \\
\hline $\mathrm{L}_{02}(8)$ & 1 & 0.4354 & 0.5016 & 0.9501 & 0.7218 & 4 \\
\hline $\mathrm{L}_{02}(9)$ & 1 & 0.3333 & 0.4199 & 0.5102 & 0.5658 & 9 \\
\hline
\end{tabular}

\section{Results Analysis}

1) The calculation result reveals that the correlation degree of impact factors of high-skilled talents' employment quality and enjoyment quality are different. Professional knowledge and skill is very important in employment, which indicates that the enterprises pay more attention to the talents' high education level, professional knowledge and skills, which are precisely basic qualities for employment, these qualities are explicit and can be shown in a short period of time. However, the key impact factors for high-skilled talents to enjoy their work lie in the professional moral, professional ideal and the degrees of approval by oneself, family and society. The Implicit, inherent and internal quality should be identified through a long time. Therefore, the cultivation of the high-skilled talents should not 
only focus on explicit knowledge and skills, but also attaches great importance to the professional ideal, professional moral and other recessive literacy.

2) As to the impact factors, high frequency does not necessarily mean the high degree of correlation. Such as professional skills in table I and table III and family factors in table II and table IV. This phenomenon tells us to judge the influence of each impact factor not only by frequency but also by correlation degree. Because the greater correlation degree, which not only has a high impact on system variables, and also has a strong influence on other factors. Therefore, it's much more scientific and reasonable to analyse the each impact factor by considering the frequency of occurrence and correlation degree [3].

\section{The Recommendations for Promoting the HTPA}

Based on the above analysis, the cultivation of HTPA should take the employment as the orientation, and the enjoyment in work as the goal. And it should pay more attention to the employment ability and sustainable development quality of high-skilled talent, as follows:

\section{A. Taking "Devotion" and "Sincerity" as the Core to Enhance Professional Moral}

Professional moral is the most important of the profession accomplishment, not only is it a normative knowledge, but also a practical ability, which highlights its true significance only in the solution of the specific, practical problems. The realization of the goal of professional moral education needs the guidance of professional code of ethics and the influence of occupation environment and in occupation morality practice. All walks of life occupation moral content is different, but the "devotion" and "sincerity" is the core content, which are the most basic requirements for practitioners. Strengthening occupation moral education of high-skilled talents, make its know occupation's life. Only with the "devotion" and "sincerity" they will work diligently and conscientiously in their own work. It not only can realize the value of one's life, but also to make its due contribution to society.

\section{B. Taking "Employment" and "Enjoyment" as the Main Clue to Reinforce Professional Ideal}

Not only knowledge and skills, but also the occupation ideal should be required in training of high-skilled talents' professional accomplishment. Marx argued that the main guidance of choosing professional ideal is human happiness and one's own perfection. What's more, the people, who work for contemporary's happiness, can perfect themselves. This shows that setting up the correct professional ideal should stand in the height of the social development, starting from the national interests and social needs and combining the realization of self value with social needs. Therefore, the highskilled talents' professional ideal should not only meet the social requirements, such as resource conservation, environmental friendly and sustainable development, but also should meet the talent's own requirements of "employment" and "enjoyment".

\section{Focusing on Social Ability to Strengthen Professional Ability}

Professional ability is the key factor in HTPA training, which has a direct impact on their employment, even sustainable employment and enjoyment in their work. The paper holds the view that "hard" ability of different position, such as professional knowledge and skills, can be obtained by short time training and learning, while the cultivation of social ability such as the ways of thinking, analysis, judgment and decision-making etc and the ability of organization, coordination, cooperation etc, is the long-term internalization process . The cultivation of HTPA should run through the whole process, from which the employment competitive and innovative ability can be improved by taking the employment as the guidance and combining their own actual situation with related occupation demand, constructing the social practice system and carrying out the mode of teaching-practiceTeaching [4] education, strengthening the cohesion and cooperation of enterprise and market.

\section{Conclusion}

On the basis of grey correlation theory, the paper analyse various influence factors of HTPA. Knowing the primary and secondary factors, it is helpful for training high-skilled talents by focusing and optimizing the social education resources. And it's better to cultivate the more competent "golden collar" talents and then to promote the development of society.

\section{Acknowledgment}

Project is supported by Hunan province education science “twelfth-five year" plan (Grant No. XJK012CZJ074)

\section{References}

[1] J. Peng, "On professional accomplishment cultivation target and structural elements in higher occupation education," Higher Education Forum, Vol. 8, pp. 125-128 Aug. 2012.

[2] J. Deng. The primary methods of grey system theory (Second Edition). pp.22-35. Wuhan: Huazhong University of Science and Technology press, 2005

[3] L. Huo, "Research on capacity building of high skilled talents", pp.3541China University of Geosciences, May.2010

[4] J. Chen, S. Xiao, "Patterns and cultivation of talents' vocational attainment" Journal of Guangzhou City Polytechnic, Vol 6.No. 2 pp.9296, June 2012 